Volume and Issues Obtainable at Center for Sustainability Research and Consultancy
Journal of Accounting and Finance in Emerging Economies
ISSN: 2519-0318 \& ISSN (E): 2518-8488
Volume 7: Issue 3 September 2021
CSRᄃ
Journal homepage: www.publishing.globalcsrc.org/jafee

\title{
Trade, Environment, Human Capital and Services Sector in Developing Countries: A Panel Data Analysis
}

Ismat Nasim, Department of Economics, Govt. Sadiq College Women University, Bahawalpur, Pakistan

*Imran Sharif Chaudhry, School of Economics, Dean, Faculty of Arts - Social Sciences, Bahauddin Zakariya University, Multan, Pakistan

Fatima Farooq, School of Economics, Bahauddin Zakariya University, Multan, Pakistan

Furrukh Bashir, School of Economics, Bahauddin Zakariya University, Multan, Pakistan

*Corresponding author's email: imran@bzu.edu.pk

\begin{tabular}{l}
\hline ARTICLE DETAILS \\
\hline History \\
Revised format: Aug 2021 \\
Available Online: Sep 2021 \\
\hline Keywords \\
Trade Openness, CO2 \\
Emission, Human Capital, \\
Services Sector Value \\
Addition, Developing \\
Countries
\end{tabular}

JEL Classification

F1, F18

\section{ABSTRACT}

Objective: This study aims to examine the influence of Trade Liberalization, Environmental Quality (CO2 Emission) on Services Sector Growth in some selected developing.

Methodology: The estimation of the study considers panel data unit root and panel data ARDL approach. The environmental quality is represented by Carbon Dioxide Emission and trade liberalization is by trade openness.

Findings: The results of Panel Unit Root test summarize that Panel ARDL is the most appropriate method of estimation for having Panel Coefficient values due to mixed order of integration for developing countries.

Implications: The empirical findings of model, in Developing Countries, Labor Force, Capital Stock, Trade Openness, Money Supply, Government Expenditure and Human Capital exert upward pressure on Services Value Addition while Carbon Dioxide Emission and Price Level is putting download pressure on Services Value Addition.

(C) 2021, The authors, under a Creative Commons AttributionNonCommercial 4.0

Recommended citation: Nasim, I., Chaudhry, I. S., Farooq, F. and Bashir, F. (2021). Trade, Environment, Human Capital and Services Sector in Developing Countries: A Panel Data Analysis. Journal of Accounting and Finance in Emerging Economies, 7 (3), 597-606.

\section{Introduction}

Services sector is the third main sector of the economy that captures an important place in the economy and its growth and development. When growth and development happens then it leads to bring the structural changes. So therefore a growing economy also changes the percentage of basic sectors mainly agriculture, industry and services with the coordination of other sectors such as rural and urban, public and private, domestic and foreign sectors. The structure of an economy 
is defined by comparing its distribution of share among three main sectors named as agriculture, industry and services in output and employment opportunities of an economy. Although the agriculture sector capture the most important place in the developing economy but by the time passes the phenomena is changed.

After losing the prominence of agriculture sector, two sectors come forward to contribute in economy's per capita growth. Two sectors are industry and services sector. This happens due to wage differentiation in different sectors. Initially the sectoral shift has started towards the industrial sector and then it moves towards services sector. Three sectors are linked together in such a way that integration of them is key path to growth for any economy. As industrial growth take place in a developing economy, things become centralized. The centralization of various services also allows to grow the services that mainly consist of transportation, information and communication sector, energy sector and business and banking sector. Most of the researcher limit the services sector to the higher education services sector or office jobs. However, the services sector is vast term and defined at large-scale.

After the consecutive shifts of industrialization and post industrialization or deindustrialization, services sector starts to develop. All developing nations experience the stages that are existed due to structural changes in consumer demand and relative labor demand and productivity in three main sectors of the economy. The services sector is a cluster of various services like;

- Trade in the economy to introduce the economy to rest of the world for the betterment of the economy and to increase the well-being of the economy

- Hotels and Restaurants business to flourish the job opportunities

- Transportation of all kind in the economy

- Tourist Assistance Activities to entertain the tourists

- Travel Agencies and Tour Operators a source of guidance for the people who want to go out of the country either for a visit, tour or immigration

- Storage and Warehouses to facilitate the firms and production sector to store their stocks

- Information and Communication Technologies to help people to make their life easy by reducing the physical efforts and to increase the different job options

- Banking and Insurance Sector being an intermediary between people who save for the future and for the financial institute who use their saving through the investors

- Real Estate and Residence Ownership to facilitate the buying and selling of the piece of land for residential purposes or for the business fixed investment

- Business and Management Consultancy to guide how to start a business with basic knowledge of it

- Accounting sector to maintain the balance of assets and liabilities

- The software is developed for various functions that allow the consumers and producers to communicate with each other

- Data Processing Services

- Architecture and Engineering Sector to build a house or a mall these services are available to all at low cost

- Technical Consultancy

- Advertisement services to introduce your business to the people and to the world.

- Public Administration to provide basic needs of the society

- Defense Services to protect the nation internally as well as externally

- Formal and vocational Education Services helps in the human capital formation and providing the educated and efficient workers with technical knowledge

- Health Services to provide the basic health services to the people publically or privately

- Religious and other Community Services to allow the citizens of the nation to perform 
their religious activities

- Legal Consultancy Services

- Recreational and Entertainment Sector

- Activities of Extra Territorial Organization

- Forestry and livestock Management and Consultancy Agencies

Trade liberalization reforms such as tariff and non-tariff obstacles faced by developing countries is very essential conditions for increasing the level of exports in the economy and this just a necessary condition not a sufficient one because developing countries have to face the issues of poor infrastructure. There are many hurdles in the way to the development for a developing economy like availability of efficient ports, adequate road maps, proper and reliable electricity and means of communications. There is lack of necessary technological requirements and technical knowhow to meet the international standard of products. The product standards that are dominating in the high valued markets are difficult to meet where the products are of nature of standardized products like sanitary measures, technical restrictions, certifications and copy rights issues. In addition, there is lack of highly needed institutions to provide stable and clear regulations to allow enjoying the gains from the global trade amalgamation.

Rwanda, among EAC countries region, is determined to become a service-oriented cluster to serve the region to be out of its interior nature. The step towards globalization of services sector is very speedy and therefore this sector is imagined a road for economic renovation (Mann, 2004). The Rwanda service sector is superset of two sectors based on categories of trade and transportation. These services consist of maintenance and wear and tear of auto vehicles, wholesales and retailer trade plus transportation services. These basic two services are integrated with other services like information and communication, real estate activities such as professional, scientific and technical activities, administrative and supported services and many more.

It is necessary to know the role of the sector on the financial health of the nation. Numerous studies are responsible for providing the empirics on this issue that services sector is seem to be a healthy sector for the whole economy as compare to agriculture and industrial sector. Same situation is also witnessed in neighboring countries where in recent decade the services sector is performing much better and with the reference of standard literature, this sector is responsible for bringing speed in economic growth only after a value addition of agriculture and then industrial development.

Indian economy largely dependent on the services sector in terms of potential employment opportunities and contribution to gross Domestic Product. This sector accommodate a wide range of economic activities come from the complicated fields of information and communication technology. Informal sector workers like hawkers, rickshaw drivers, pursue this sector fruit sellers etc. because these group activities are also considered as a part of services sector. Therefore, the major comparison analysis of these states can be done by using employment services by considering main workers. The prosperous growth of services sector in India suggested the issue of sustainability in a broader way. Empirical studies showed interdependence of different sectors either an input-output framework used (Hansda, 2001) or through econometric modelling (Sastry et al, 2003). In the literature, Bhattacharya et al (2012) had studied the e-services sector growth in India. All these studies done already worked by assuming the economy a closed one, and therefore commodity producing sector of the country has no role in determining a state's services performance.

Now services sector is also growing in Pakistan and contributing more than $50 \%$ (Pakistan Bureau of Statistic) of the Gross Domestic Product of Pakistan. The evidences came from the 
past trends of services sector contribution in Pakistan's overall economic growth are increasing over the time-period. Same as other developing countries, this increase in services sector share substitute the share of agriculture sector in the economy. Agriculture losing its significant shares in the Gross Domestic Product of Pakistan because this sector fails to generate the required level of employment opportunities and income as well. A large number of populations have shifted from agriculture sector to the industry, services sectors as these two sectors are creating more employment, and wages are high here as compared to agriculture.

However, when the services sector is flourishing very rapidly then it may face the issue of labor shortage in social service activities that should be highlighted and identified with some new basic measurements for the value of social services. Here any economy cannot forget the role of women that is intensively visible in the world of today is happening. A woman is facing the tread every province of the activities with self-belief and proven competence. Her entry into male oriented of executive role in management affairs is a significant success under the light if many constraints. Services sector increases the income level of the peoples of the society, they are affording more other services, and able to spend on quality services like education, health, better means of transportation. Small and medium enterprises can help to meets the need of the people for more and more services with growth of the income levels and basic standard of living.

The share of the services sector is the maximum one out of three sectors and the resources are income elasticity of demand, open policies and reforms, growth of communication services, business, banking and trade services. However, these services will be better by innovation based on knowledge-intensive services, close-customer relation, network-based services, information and technology networking, supplier dominant services.

The trade liberalization leaves its impact overall economy specially the sectorial growth of any economy. Each of the sub-sector plays a vital role in any economy by influencing living standard of people, unemployment, poverty and inequality. These are themselves influenced by the trade. That means trade indirectly via each sector of the economy impacts the overall economy. In so far as main objective is to study the effectiveness of Trade Liberalization and Environmental Quality on Sectoral Growth of Developing Countries.

The present study is different and significant as this study is filling the research gap by providing empirical relationship of environmental quality on services sector of the economy as there is no literature available to show such effect. The research question of the study is how is empirical relationship of environmental quality on services sector can be measured without any literature support?

\section{Literature Review}

This section covers all the research work done by research investigators from all over the world based on the relationship between trade liberalization that is mainly represented by trade policies of restrictions or subsidies and services sector growth.

World Bank data from 1976 till 2014 was used by Ajmair (2017) to study the structural changes done in 1950's in Pakistan that resulted in GDP growth. Conclusions of the paper depicted a strong negative impact between CPI and GDP from services sector but net FDI had a direct impact. He recommended increase in foreign direct investment, gross national expenditures and external debt to accomplish Longrun economic growth.

Another study was done by Ajmairet al. (2016) studied the factors resulting in increased growth of services sector in Pakistan using time series data from 1975 to 2014. They used ARDL approach to show that variables like population growth rate, growth in market size, increase in 
exports as well as government expenditures were major factor to influence this sector. They recommended increasing growth of services sector in order to increase the overall economic growth in Pakistan.

Morrar and Gallouj (2016) explored the gap between productivity of services and manufacturing sector in Palestine along with the exploring the heterogeneity between different sectors within the country. They further studied the impact of services sector growth on overall productivity of the economy including political factor. The paper focused on the challenges faced by the Palestine economy that were firstly the highly dependent on Israeli economy, secondly the restrictions imposed by the Israel, and lastly, the lack of finances. The results on the basis of 234 sub-sectors over 1995 to 2009 pointed out that growth in intermediate consumption did not mean strong production of that sub-sector. But the sub-sectors were number of firms increased did show increase in labor productivity. They suggested increasing labor productivity in services sector by absorbing numerous unskilled, unemployed workers. Furthermore, they recommended in adopting tradition policies in order to increase employment level in services sector.

Uwitonze and Heshmati (2016) analyzed services sector of Rwanda in order to explore the determinants of that sectorial growth. This study deduced that training given to the professionals, increase in labor force participation rate, and increased access to finance, information and communication technologies applications, and tax systems drove the services sectors in Rwanda. Access to finance that had grown over the time put a positive impact on dependent variable. Some other variables like acquisition of fixed assets, capital used by the firms, turnover of firms providing services were also responsible for increase in innovations. Furthermore, they recommended gender sensitive policies to give equal change to women in the relevant fields, expand the ICT applications, regulate the monetary policy in the favor of financial assistance, and create space for the foreign trade policy to promote existing economic integration.

Das and Raut (2014) studied the pattern of growth in services sector in India along with the impact this growth created in overall development in the country. They utilized the data set from various sources ranging from 1999 till 2012. The research was based on the secondary data from 1990 to 2012 from different sources. They found out that the services sector in India was diverse and this resulted in innovations and development support in other sectors of the country.

Lashmi and Kumar (2012) presented the efforts that had been made to study the growth of Indian services sector and its impact on other sectors like industry and agriculture. For this they used secondary data from 1999 till 2010. They found that growth of this sector as compared to other two sectors was much more and thus made it the fastest growing and most contributing sector in India to her GDP. They put the responsibility of this fast growth on increased need of services and high income elasticity of this services demand in India. They further, pointed out that there is still room for growth in services sector in India.

Chakravarty (2006) studied using data from India to understand the determinants of growth in services sector. The yearly time series data had been collected from 1980 to 2003 on output and employment with some supporting variables. The empirical findings showed that services sector growth during the time of study was a common experience of all states in India, with varied experiences by all. They recommended achieving extraordinary growth rate in addition to diversification in services sector in order to reach desired prosperity level.

\section{Data and Methodology Data and Methods}

For the Panel data of 63 developing countries, the interval of time from 1990 to 2018 is decided in this study. World Bank Organization developed World Development Indicators and its data 
was provided on its website \& Penn World Table 9.1 is developed by Groningen Growth and Development Centre which is one of the Departments of University of Groningen, Netherlands are major sources of data collection in this research. This study follows Panel Unit Root test and Panel ARDL Test to obtain the empirics of the study.Fresh upcoming writings advocate that unit root tests for panel sets have higher power than individual time series' unit root tests. E-Views can run the computation of one of the following five panel unit root tests that are (LLC) abbreviated as Levin, Lin and Chu (2002), the Breitung (2000), IPS (Im, Pesaran and Shin) (2003), Fishers' tests that are based on using ADF augmented Dicky Fuller test and PP (Phillips and Perron) tests.

\section{Econometric Methodology}

The econometric model is specified to show the impact of trade, environment and human capital on services sector output for Developing Countries as given below;

$$
\begin{gathered}
S R V L=d_{0 i}+d_{1 i} \text { LBFRC }_{i t}+d_{2 i} \text { CPSTK }_{i t}+d_{3 i} \text { TRDOPN }_{i t}+d_{4 i} C R E M_{i t}+d_{5 i} G D P D F_{i t} \\
+d_{6 i} \text { HMCP }_{i t}+d_{7 i} \text { BMN }_{i t}+d_{8 i} G V E X_{i t}+e_{i t}
\end{gathered}
$$

Where,

SRVL= Services Value Addition

LBFRC = Labor Force

CPSTK $=$ Capital Stock

TRDOPN $=$ Trade Openness

CREM $=$ Carbon Dioxide Emission

GDPDF $=$ GDP Deflator

HMCP = Human Capital Index

BMN $=$ Broad Money

GVEX = Government Final Consumption Expenditure

Error term is denoted by $e_{i}$, country is shown by ' $i$ ' and years are mentioned here by ' $t$ '.

\section{Results and Discussions}

\section{Panel Unit Root Results in Developing Countries}

There are so many methods to check order of integration or to check problem of unit root in panel data variables and one of those methods is Im, Pesaran and Shin W test. In table 1, probability values of Carbon Dioxide Emission, Capital Stock, Trade Openness, Broad Money, Government Expenditure, GDP Deflator and Human Capital are less than 0.10 at Level by including Intercept or Trend \& Intercept and it may be concluded that Carbon Dioxide Emission, Capital Stock, Trade Openness, Broad Money, Government Expenditure, GDP Deflator and Human Capital are stationary at Level. On the other side, if Intercept and Intercept \& Trend are added Level, so probability values of Services Value Addition and Total Labor Force are greater than 0.10 demonstrating Unit Root problem in these variables. Services Value Addition and Total Labor Force are checked at $1^{\text {st }}$ Difference by including Intercept and Trend \& Intercept and observed probability values are less than 0.10 which may lead towards the rejection of Null Hypothesis of Unit Root Problem at $1^{\text {st }}$ difference so it may be concluded that Services Value Addition and Total Labor Force integrated of order 1 if Intercept and Trend \& Intercept are added.

\begin{tabular}{|c|c|c|c|c|}
\hline \multirow{2}{*}{ VARIABLES } & \multicolumn{2}{|l|}{ Intercept } & \multicolumn{2}{|c|}{ Trend and Intercept } \\
\hline & Test Statistics & $P$-Value & Test Statistics & $P$ - Value \\
\hline \multicolumn{5}{|l|}{ LEVEL } \\
\hline Services Value Addition & 11.30 & 1.00 & -0.14 & 0.44 \\
\hline Total Labor Force & 2.26 & 0.98 & -1.24 & 0.10 \\
\hline Capital Stock & 4.49 & 1.00 & -4.96 & 0.00 \\
\hline $\begin{array}{l}\text { Trade Openness/ } \\
\text { Trade Liberalization }\end{array}$ & -4.45 & 0.00 & -6.38 & 0.00 \\
\hline
\end{tabular}

Table 1: Im, Peasaran\& Shin W Test -Developing Countries 


\begin{tabular}{|l|l|l|l|l|}
\hline $\begin{array}{l}\text { Carbon Dioxide Emission/ } \\
\text { Environmental Quality }\end{array}$ & 2.60 & 0.99 & -8.25 & 0.00 \\
\hline Government Expenditure & 8.27 & 1.00 & -7.40 & 0.00 \\
\hline Broad Money & 6.05 & 1.00 & -2.31 & 0.01 \\
\hline GDP Deflator & -19.63 & 0.00 & -11.24 & 0.00 \\
\hline Human Capital & 0.79 & 0.78 & -3.41 & 0.00 \\
\hline $1^{\text {ST }}$ DIFFERENCE & -1.00 & -18.15 & 0.00 \\
\hline Services Value Addition & -21.87 & 0.00 & 0.00 \\
\hline Total Labor Force & -13.39 & 0.00 & -12.54 & \\
\hline
\end{tabular}

\section{Trade, Environment and Services Value Addition}

The influence of trade liberalization and environmental quality with Services value addition in Developing countries is observed and the results are reported in table 2.

According to the expectation, semi-skilled or unskilled labor force of DCs' may have positive effect on Services Value Addition because of weak services sector of DCs'. The empirics are validating that labor force of developing countries may have positive impression on Services value addition due to availability of Highly Skilled Labor and much improved services sector that is consistent with the results of Edeme et al. (2016), that is also concluded that labor force participation also positively impacts the economic growth of the ECOWAS region. Approximately, labor force has positive prediction by 0.21 percent in Services value addition in all developing countries in longer period of time with statistically significant probability values.

As regards to Capital stock which is included in this study to show the effect of Capital, it shows that higher capital stock to boost services sector in developing countries may increase services value addition in developing countries, the value of coefficient respectively is 0.08 . It shows that Capital Stock is found as a source of higher Services Value Addition in the longer period of time that is supported by Gilbert et al. (2013) for economic growth. Services Value Added has positively predicted by Capital Stock in the long-run due to existence of co-integration and it is augmented in developing countries by 0.08 percent approximately empirically.

Carbon Dioxide Emission is a representative of Environmental Quality in Developing Countries. If environmental quality is improved so it shows that there would be clean environment and hence high quality of life and productivity may increase in return. It shows the presence of pollution in the environment in current scenario which may be due to intensive use of machinery for luxury purpose like Air Conditioners, Power Generators etc. DCs'. Intensive use of machinery for luxury purpose may be harmful for Services Value Addition DCs'. The value of coefficient is 0.11 with significant probability value denoting that one percent more carbon dioxide emission may decrease services sector by 0.11 percent in DCs' in longer period.

Trade Liberalization is the vital factor for services value addition in case of overall developing countries there is positive sign attached with Trade in case of these countries. Services sector would be expanded in the long run if these developing countries are concentrating and improving their export sector in terms of semi-furnished or fully furnished goods and services or increasing trade with overall world. Trade openness is having statistically significant coefficient value with services value addition in the long run and it may be interpreted as one percent increase in trade liberalization may result in 0.001 percent higher services value addition approximately in developing countries.

For tracing the effect of Monetary Policy, Broad Money is taken in this study as explanatory variable. Monetary Policy is one of the goals of Macroeconomics to get higher Economic Growth and Higher Services Value Addition in the longer period of time. Its value of coefficient is 
positive in situation of Developing Countries that is 0.06 percent. It may be due to the fact that these countries are already having shortage of funds so excess funds may create inflation which may reduce Services Value Addition in the longer period of time.

Taking Price Stability, the study takes GDP Deflator which is supposed to be negatively related with Services Value Added supported by Uremadu and Onyele (2016) and Faridi (2012). It is quite natural that increase in price level will reduce the purchasing power of the people and in response demand for goods and services will reduce and it will give negative impression on services value addition. In Developing Countries, increase in GDP Deflator by one percent will reduce services value addition by 0.009 .

Fiscal Policy is a key policy for the government for achieving higher growth rates in the long run by the developing economies. Due to expansionary fiscal policy, there would be higher level of expenditure by the government in the economy which would enhance developmental and nondevelopment projects in the economy. Due to these developmental projects, services value addition would ultimately increase in the long run. Similar to this, the econometric results of this study also provides positive contribution of Government Final Consumption Expenditure towards Services Value Addition in case of Developing Countries like the study of Mehrara and Baghdanpour (2016) for 34 developing countries. Services Value Added has positively predicted by Government Expenditure in the long-run due to existence of co-integration and it is augmented in developing countries by 0.09 percent approximately empirically.

Human Capital is the most important factor for Services Sector Development in Developing Countries in the long run. Its coefficient is measured as 1.61 in Overall Developing Countries showing more elastic effect on Services Value Addition with statistically significant in developing countries only. Human Capital is obtained as positive with Services Value Addition in Developing Countries in the longer period of time denoting that Improved Technical Skills and Educational Skills to the people related to Services Sector may enable workers to get higher production levels in the Services Sector in the longer period of time.

Short run results are also calculated for Developing Countries, are given in lower portions of the tables with Short Run Equation in which COINTEQ01 is the Speed of Adjustment term/ Cointegrating Term/ (ECT) Error Correction Term. The term is measured is -0.18 with statistically coefficient value. The value illustrates that convergence would be occurred in the direction of long run equilibrium due to any short run disturbance and on average estimated time would be approximately 4.5 years in developing countries.

Table 2: Services Value Addition in Developing Countries

\begin{tabular}{|c|c|c|c|c|}
\hline Variable & Coefficient & Standard Error & t-Statistic & Probability \\
\hline \multicolumn{5}{|l|}{ Long Run Equation } \\
\hline Labor Force & 0.309086 & 0.041320 & 7.480269 & 0.0000 \\
\hline Capital Stock & 0.084426 & 0.008092 & 10.43305 & 0.0000 \\
\hline \begin{tabular}{|l|} 
Environmental Quality/ \\
Carbon Dioxide Emission
\end{tabular} & 0.113380 & 0.015565 & 7.284294 & 0.0000 \\
\hline $\begin{array}{l}\text { Trade Liberalization/ } \\
\text { Trade Openness }\end{array}$ & 0.001305 & 0.000211 & 6.189676 & 0.0000 \\
\hline Money Supply & 0.067283 & 0.008779 & 7.663862 & 0.0000 \\
\hline Price Level & -0.009469 & 0.002760 & -3.430735 & 0.0006 \\
\hline Government Expenditure & 0.096729 & 0.014154 & 6.834113 & 0.0000 \\
\hline Human Capital & 1.611944 & 0.083373 & 19.33402 & 0.0000 \\
\hline \multicolumn{5}{|l|}{ Short Run Equation } \\
\hline COINTEQ01 & -0.181406 & 0.030028 & -6.041225 & 0.0000 \\
\hline D(LSERVALCON(-1)) & 0.138097 & 0.041078 & 3.361817 & 0.0008 \\
\hline D(LSERVALCON(-2)) & -0.070962 & 0.032880 & -2.158225 & 0.0311 \\
\hline D(LLABFORCE) & 0.175106 & 0.413576 & 0.423394 & 0.6721 \\
\hline
\end{tabular}




\begin{tabular}{|l|l|l|l|l|}
\hline D(LCAPSTOCK) & 0.097128 & 0.035649 & 2.724568 & 0.0065 \\
\hline D(LCO2EM) & 0.034778 & 0.017627 & 1.973006 & 0.0488 \\
\hline D(TRADOPEN) & $-3.33 \mathrm{E}-05$ & 0.000264 & -0.126445 & 0.8994 \\
\hline D(LBRMN) & 0.046955 & 0.015726 & 2.985859 & 0.0029 \\
\hline D(LGDPDEFL) & -0.029829 & 0.028938 & -1.030772 & 0.3029 \\
\hline D(LGOVEXPCUR) & 0.083089 & 0.022931 & 3.623502 & 0.0003 \\
\hline D(LHUMCAP) & -0.376272 & 0.693717 & -0.542399 & 0.5877 \\
\hline CONSTANT & 1.868465 & 0.298208 & 6.265642 & 0.0000 \\
\hline
\end{tabular}

\section{Conclusion}

The objective of the study is to study the effectiveness of Trade Liberalization and Environmental Quality on Sectoral Growth of Developing Countries. For the Panel data of developing countries, the interval of time from 1990 to 2018 is decided in this study. World Bank Organization developed World Development Indicators Penn World Table 9.1 are major sources of data collection in this research. The estimation in this study considers Im, Pesaran and Shin W Test (IPS) as Unit Root Test, Panel ARDL Long run Analysis for calculations of Elasticities. In the results of Services Value Addition models, in DCs'-Developing Countries, Labor Force, Capital Stock, Trade Openness, Money Supply, Government Expenditure and Human Capital are exerting a pushing upward impact on Services Value Addition whileCarbon Dioxide Emission and Price Level are putting download pressure on Services Value Addition.

Carbon Dioxide Emission positively correlates with services sector value needs to reduce the carbon emission with efficient and modernized machinery side by side taxation should be used to monitor the environmental quality properly in developing countries. The positive and very low effect of Trade Openness can be improved by producing more quality products that can compete in the international market. Therefore, it is suggested to meet the challenges in the national and international markets; the quality products must be increased so that the exports become an encouraging factor to increase the services productivity developing nations. Human Capital is boosting Services Value Addition suggesting that more trained and educated human resources will enable the developing countries to get the optimal level of output from services sector units.

\section{References}

Ajmair, M., Gilal, M., \& Hussain, K. (2016). Determinants of Services Sector Growth in Pakistan. European Scientific Journal, 297. https://doi.org/10.19044/esj.2016.v12n34p297

Ajmair. M. (2017). Determinants of Services Sector Growth in Pakistan: A Time Varying Parametric Approach. Industrial Engineering Letters. Vol. 7. No. 3, 17-23.

Bhattacharya, D., Gulla, U. and Gupta, M.P. (2012), "E-service quality model for Indian government portals: citizens' perspective", Journal of Enterprise Information Management, Vol. 25 No. 3, pp. 246-271. https://doi.org/10.1108/17410391211224408.

Chakravarty. D. (2006). Growing Services in India: An Inter-Sectoral Analysis Based on StateLevel Dat. Economic and Political Weekly. Vol. 41. No. 27/28, 3061-3065+3067.

Das. L. and Raut. R. (2014). Impact of Change in service Sector in India in Shaping the Future of Business and Society. Procedia Economics and Finance. Vol. 11, 795-803.

Edeme. R. K., Ifelunini. I. A. and Nkalu. N. C. (2016). A comparative Analysis of the Impact of Agricultural Exports on Economic Growth of ECOWAS Countries. ACTA oeconomicaPragensia. Volume 24, No. 05, 31-46.

Faridi. M. Z. (2012). Contribution of Agricultural Exports to Economic Growth in Pakistan. Pakistan Journal of Commerce and Social Science. Vol. 6 No. 01, 133-146.

Gilbert. N. A., Linyong. S. G. and Divine. G. M. (2013). Impact of Agricultural Export on Economic Growth in Cameroon: Case of Banana, Coffee and Cocoa. International Journal of Business and Management Review. Vol. 01, No. 01, 44-71.

Hansda, S (2001): "Sustainability of Services-led Growth: An Input-Output Analysis of the 
Indian Economy", Reserve Bank of India Occasional Papers, Vol 22, pp 73-118.

Lashmi. P. and Kumar. S. (2012). A study of Factors Affecting the India's Service Sector: An Econometric Analysis. International Journal Of Business Management and Economic Research. Vol 3. No. 2, 490-497.Least-developed Countries. UNCTAD Review, January, $1-6$.

Mann, C. L. (2004). Globalization of services: why, how much, and what to do about it - some issues for the 'North' and the 'South'. Institute for International Economics, 1-9.

Mehrara. M. and Baghbanpour. J. (2016). The contribution of Industry and Agriculture Exports to Economic Growth: The Case of Developing Countries. World Scientific News. Vol. 46. 100-111.

Morrar. R. and Gallouj. F. (2016). The Growth of the Services Sector in Palestine: The Productivity Challenge. Journal of Innovation Economics and Management. Vol. 1, No. 19, 179-204.

Sastry, D., Singh, B., Bhattacharya, K., \& N. K. Unnikrishnan. (2003). Sectoral Linkages and Growth Prospects: Reflections on the Indian Economy. Economic and Political Weekly, 38(24), 2390-2397. Retrieved May 27, 2020, from www.jstor.org/stable/4413682.

Uremadu. S. O. and Onyele. K. O. (2016). The Impact of Selected Agricultural Exports on the Growth of the Domestic Economy. Academia Journal of Agricultural Research. Vol. 4. No. 5, 281-291.

Uwitonze. E. and Heshmati. A. (2016). Service Sector Development and its Determinants in Rwanda. IZA Discussion Paper No. 10117. 